\title{
Attitudes Toward Business Ethics And Degree Of Opinion Leadership Of Future Managers In The United States, Finland, And China
}

\author{
Charles Comegys, Merrimack College, USA \\ Jaani Väisänen, Tampere University of Technology, Finland \\ Robert A. Lupton, Central Washington University, USA \\ David R Rawlinson, Central Washington University, USA
}

\begin{abstract}
The purpose of this study was to compare the attitudes towards business ethics of future managers in three countries: the United State, Finland, and China, and determine whether business ethics attitudes differed by the student's major, class year, GPA, gender, age, and the number of ethics and religious studies courses completed. Additionally the relationship between the degree of opinion leadership and ethical attitudes was examined to determine if opinion leaders exhibited different attitudes towards business ethics.
\end{abstract}

Keywords: Business Ethics; Business Education; Students' Ethical Attitudes

\section{INTRODUCTION}

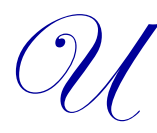

nfortunate unethical events are continuing in the business arena and now more than ever these business judgmental shortcoming focus attention on the ethics of business executives.

The Justice Department reported that GlaxoSmithKline LLC pleaded guilty to criminal charges of illegally marketing drugs and withholding safety data from U.S. regulators. According to The Wall Street Journal in July 2012 Glaxo paid a $\$ 3$ billion combined criminal-civil fine. In 2008 Bernard Madoff's staggering ethical violations caused a horrific financial meltdown. Earlier the Washington Post (2006) reported that the FBI pursued criminal conspiracy charges against executives at a New York software maker, Converse Technology Inc., as well as against 44 other companies for backdating stock option awards. The Securities and Exchange Commission also examined 80 additional companies. The Wall Street Journal in March 2006 questioned the timing of stock option awards at six companies including UnitedHealth, Converse Technology, and Affiliated Computer Services. The Journal further reported on June $16^{\text {th }}$ that Microsoft awarded stock grants to employees at monthly lows during the 1990's. On this same day Home Depot also disclosed that some of their executives had received stock options with the exercise prices below the market price on the date of issue.

According to Institutional Shareholder Services (2006) at least 50 companies including Apple Computer Inc. and Monster Worldwide Inc. had disclosed criminal, regulatory or internal investigations into the backdating and/or manipulating the timing of stock option grants to senior executives. This deceitful practice using corporate position and power continues the litany of executive scandals in recent years at Enron Corp., WorldCom Inc., Tyson, K-Mart, Aldelphia, Tyco, the law firm of Milberg Weiss Bershad \& Schulman, Arthur Andersen, Boston's Big Dig contractor Modern Continental Construction Co., and Hewlett-Packard.

Educational institutions are not exempt from ethical problems either. Evidence of academic dishonesty abounds. A survey of graduate students in the United States and Canada found that 56 percent of graduate business students admitted to cheating in the past year compared with 47 percent of non-business students. Students 
commented that it was an accepted business practice and one they will need to succeed in their professional lives (McCabe, 2006). This does not fare well for ethical behavior of the managers of the future.

Thus colleges and universities must continue to address business ethics as they prepare and train the next generation of executives. Educational institutions should be concerned with environmental factors and curricular changes or modifications that may impact their graduating students and our future business leaders. For example, the George Washington University School of Business recently hosted an AACSB Ethics and Governance Conference to assist business schools in assessing leadership roles in ethics. The purpose of the event was to explore the future of business ethics and address opportunities and challenges to achieve success in ethics through education. Although the Association to Advance Collegiate Schools of Business (AACSB) has supported the teaching of business ethics as early as the 1980s, they are now stepping up their efforts in this area. The Ethics Education Task Force created in June 2004 by AACSB published a report on "Ethics Education in Business Schools." In the forward to that report, Susan Philips challenged business educators by her statement that "the crisis in business ethics is not only a challenge for companies but also an opportunity to strengthen management education" (Report of the Ethics Education Task Force, 2004, p.7). AACSB's renewed resolve concerning ethics education in the curriculum is further revealed in the Task Force Report statement that business schools must "renew and revitalize their commitment to the centrality of ethical responsibility at both the individual and corporate levels in preparing business leaders for the twenty-first century" (Report of the Ethics Education Task Force, 2004, p.9). AACSB continued its firm commitment to ethics education with the launch of its new Ethics Education Resource Center hosted on its website.

\section{Business Ethics and Attitudes Literature Review}

The increasingly global economy necessitates a study of ethical attitudes both within and across cultures. A 1988 article written by Preble and Reichel reported the results of using the Attitudes Toward Business Ethics Questionnaire (ATBEQ) to compare the attitudes of American and Israeli management students. Statistically significant differences were found between the two groups on nineteen of the thirty statements. In many instances, the authors claimed that, although the differences were significant, they were not necessarily meaningful. The authors found that both groups "held relatively high moral standards" (Preble and Reichel, 1988, p. 941). The U.S. students disagreed that "business decisions involve a realistic economic attitude and not a moral philosophy" while the Israeli students expressed mild agreement. U.S. students also disagreed that "business ethics is a concept for public relations only" while the Israeli students expressed neutrality.

Small (1992) continued the study of student attitudes toward business ethics by comparing data collected from students in Western Australia to data collected by Preble and Reichel for both U.S. and Israeli students. The attitudes of the U.S. and Australian-based students were similar although ten statistically significant differences were noted. The attitudes of the Israeli students appeared less similar to those of the Australian students with nineteen significant differences noted. Small concurred with the comment by Preble and Reichel declaring that the differences found were not particularly meaningful. There were no instances where one national group expressed strong agreement with a specific statement while a second group expressed strong disagreement with the same statement.

In 1999, Lin published a study using ATBEQ to compare attitudes of Taiwanese students to those of students from the U.S. and Israel (Preble and Reichel, 1988), and Australia (Small, 1992). Lin noted that the Chinese students had more moderate attitudes and attributed it to cultural differences whereby the Chinese rarely express strong agreement or disagreement (Lin, 1999, p. 644). To correct for this cultural difference, Lin added a ranking component using values of the mean response to each statement in order to explain the perceived degree of agreement or disagreement. The lowest mean was given a rank of one (1) out of thirty and the highest mean was a given a rank of thirty (30). Students showed the greatest disagreement with the item ranked number one and the highest level of agreement with the statement ranked number thirty. Lin compared the rankings by calculating, for each item, the differences in ranks between groups. Lin suggested that the ranking component be added to aid in the interpretation of comparative data. The overall research findings reported by Lin indicate "a pragmatic, resultfocused, and profit-oriented younger generation in Taiwan" (Lin, 1999, p. 652). 
Moore and Radloff extended the study using the ATBEQ to measure student attitudes in South Africa. In their study, the determination of significant differences between groups (U.S., Israel, Australia, and South Africa) was based on finding significant differences on at least 50 percent of the statements. On this basis, only the Israeli students were found to differ significantly from the South African students. The authors suggest that all results be viewed holistically. The cumulative effect of the differences should be viewed as meaningful rather than merely viewing one question at a time. Thus, finding 50 percent of the statements to elicit significant differences should be viewed as a finding of differences in ethical business attitudes between national samples (Moore and Radloff, 1996, p. 868). Using their basis for determining significant attitudinal differences, significant differences would be reported between 1) U.S. and Israeli students, 2) Israeli and Australian students, 3) Taiwanese and U.S. students, 4) Taiwanese and Israeli students, and 5) Taiwanese and Australian students.

Sims and Gegez (2004) provide a five nation comparative study involving the United States, Israel, Western Australia, South Africa, and Turkey. They reported differences between the graduate business students in Turkey and students from all other countries. Significant differences in attitudes were reported on fourteen (14), fifteen (15), fifteen (15) and sixteen (16) items respectively for the comparisons with U.S., Israel, Western Australia and South Africa.

In 1997 Grunbaum investigated the attitudes of future managers towards business ethics comparing Finnish and American business students. A self designed instrument was used instead of ATBEQ. The findings reported that there were only small attitudinal differences between Finnish and US students. Students in both countries were found to understand distinctions between acting legally and ethically, and both groups felt that a manager's job included participation in solving social problems as well as deliberation on moral issues.

All of the studies described above contribute to an increase in understanding of cultural differences with respect to attitudes towards business ethics. In the increasingly global economy, it is imperative that organizations discuss differences in attitudes and find ways to reduce conflict with respect to ethical decision-making. Although a respect for diversity must be fostered, a collective agreement on professional standards is necessary to reduce or eliminate ethical conflict resulting from diverse cultures and differing perceptions of right and wrong (Ferrell, 1999, p. 226).

Business schools are taking an increased interest in ethics education. The fall 2004 issue of BGS International Exchange explored business ethics in response to the business scandals of 2001 and 2002 and the fall 2006 issue announced an organizational focus on "Ethical Business Leadership." John Wholihan, President of Beta Gamma Sigma, the honor society serving business programs accredited by AACSB International, wrote that the Board plans "to develop ways to encourage business leaders to adhere to the highest ethical standards, and to show that this is one of the most important aspects of leadership in the $21^{\text {st }}$ century" (Wholihan, 2006, p. 2).

AACSB International, the Association to Advance Collegiate Schools of Business, the premier business school accrediting agency, firmly supports ethics education as an integral part of any business curriculum. AACSB now hosts an Ethics Education Resource Center on its website and in June 2004, the Ethics Education Task Force established by AACSB published a report on "Ethics Education in Business Schools."

The purpose of this study was to compare the attitudes towards business ethics of future managers in three countries: the United States, Finland, and China and determine whether ethical attitudes differed by the student's major, class year, GPA, gender, age and the number of ethics and religious studies courses completed. Additionally the relationship between the degree of opinion leadership and ethical attitudes was examined to determine if opinion leader's attitudes towards business ethics differed.

\section{METHODOLOGY}

\section{Questionnaire}

The survey consisted of the Attitude Towards Business Ethics Questionnaire (ATBEQ - see Exhibit 1) (Preble and Reichel 1988), the Revised Opinion Leadership Scale (see Exhibit 2) (Childers 1986), and questions 
gathering appropriate demographic information including gender, age, major area of study, approximate overall GPA, year in school, and the number of ethics and religious studies courses completed in college.

The ATBEQ was originally developed by Neumann and Reichel based on "Values Clarification Exercises" of Stevens (1979) and was published in the work of Preble and Reichel in 1988. The questionnaire consists of thirty statements with a five point Likert scale for each item ranging from 1 "disagree strongly to 5 "agree strongly." The statements are "related to various business philosophies like Social Darwinism, Machiavellianisn, Objectivism, and Ethical Relativism" (Preble and Reichel, 1988, p.943).

The Opinion Leadership Scale is the result of the work of Childers (1986) who modified the selfdesignating method first introduced by King and Summers (1970). An earlier version developed by Rogers (1961) and subsequently reported by Rogers and Cartano (1962), was used to study the diffusion of new farm innovations among Ohio farmers in 1957. The Opinion Leadership Scale is a six-item scale that gauges the degree of opinion leadership for a specific product category or topic. The scale was self-administered as part of the questionnaire. Lower scores on the scale indicate a person reports herself/himself as informing and persuading others whereas higher scores suggest a person has very little opinion leadership.

The questionnaires used in the United States, Finland and in China were identical except the Finnish students responded to the questionnaire in Finnish and the Chinese students had a choice of responding to either an English version or a Chinese version of the questionnaire. The content of each question was carefully translated to Chinese and Finnish in order to match the English version.

\section{Unites States - Sample and Data Collection}

The questionnaire was completed by a quasi random convenience sample of undergraduate students at six different colleges and universities located in the northeast region of the United States. Intercepts at high student traffic areas, such as student cafeterias and campus centers, were used to accomplish survey completions. The survey was self-administered in order to eliminate any interviewer-evaluation apprehension by the respondents (Hill 1995) and a free candy bar incentive was also employed. Respondent anonymity was protected by having completed questionnaires deposited directly into a survey response box. Completed questionnaires were collected from 780 undergraduate students. This sample included 53.9 percent women (417) and 46.1 percent men. Freshmen made up 27 percent of the sample (209), sophomores accounted for 29.2 percent (226), junior respondents (212) were 27.4 percent, and 16.5 percent were seniors. The average age of the US respondents was 19 years and 7 months and the age range was 17 to 50 years old.

\section{Finland - Sample and Data Collection}

The Finnish data were gathered at a large university in Tampere, Finland. The questionnaires were distributed in classes and around campus at high student traffic areas. The survey was also self-administered in Finland and anonymity was emphasized. A free coffee ticket was offered as an incentive for all respondents. The quasi random convenience sample gathered data from 147 undergraduate students in Finland. Freshmen (41) accounted for 28.5 percent of the sample, 9.7 percent were sophomores (14), juniors represented 27.1 percent (39), and seniors (31) made up 21.5 percent of the Finnish sampling. The Finnish students' ages ranged from 18 to 33 with an average age of 22 years old.

\section{China - Sample and Data Collection}

The Chinese student sample was collected from the campus of a large university in China. Data were gathered in classes. Respondents were repeatedly told, orally and in writing, that their responses would be anonymous and confidential. The quasi random convenience sample gathered data from 196 undergraduate Chinese students. Eighty-two responded to the Chinese questionnaire version and 114 opted for the English version. There were no freshmen students in this sample. Sophomores (130) consisted of 71.4 percent, juniors (45) accounted for 24.7 percent, and the remaining 3.3 percent of these respondents were seniors (6). The average age of the Chinese students was 21 years old. The age range was 18 to 24 years old. 


\section{RESEARCH QUESTIONS}

Nine research questions were investigated:

1. $\quad$ Are students' attitudes toward business ethics different by country?

2. Are students' attitudes toward business ethics different by student major?

3. Are students' attitudes toward business ethics different by class year?

4. Are students' attitudes toward business ethics different by overall GPA?

5. Are students' attitudes toward business ethics different by gender?

6. Are students' attitudes toward business ethics different by age?

7. Are students' attitudes toward business ethics different by the number of ethics courses completed?

8. Are students' attitudes toward business ethics different by the number of religious studies courses completed?

9. Are students' attitudes toward business ethics related to their degree of opinion leadership?

The nine research questions were examined using the ATBEQ results. Significant differences were determined using the methodology of Moore and Radloff (1996, p. 868). This method considers the cumulative impact, rather than individual $t$-tests. Thus, significant differences must have been found on 50 percent or more of the items. Additionally for the country comparison research question, the Lin methodology was applied. Lin suggested that, to facilitate comparisons, particularly comparisons across cultures, the ranking differences should be examined. This methodology considers the range of mean values, "the difference between the highest and lowest item mean" (Lin, 1999, p. 644).

\section{Conditions To Be Met To Conclude Significant Differences}

For the differences to be significant, the following conditions must be met:

1. the analysis of variance must provide a significant result at $\mathrm{p}<0.05$

2. of these, the t-test significances between two items must be $p<0.05$

3. significant differences must be found on at least 50 percent of the ATBEQ statements

4. for the country comparison, the difference between the two item ranks must be $\geq 5$

\section{RESULTS AND ANALYSIS}

\section{Differences By Country}

First, the differences in the ATBEQ statements were broken down by the three countries participating in the research: USA, China, and Finland. Pairwise t-testing provided 26 statements where there were differences between at least two countries. When looking at the statements where Finns and Chinese agreed and disagreed the most, one can make certain assumptions. It seems that Finns tend to separate the monetary gains of business and business ethics. For example, Finns agreed the most with statements like "The only moral of business is making money," "Business decisions involve a realistic economic attitude and not a moral philosophy," and "The main interest of shareholders is maximum return on their investment." In all of these statements, the Chinese disagreed the most. The Chinese also seem to put much more faith in their authoritative figures and superiors, as they agreed the most with the following statements: "Act according to the law, and you can't go wrong morally" and "The lack of public confidence in the ethics of business people is not justified." Finns, once again, exhibited the opposite behavior. Even though the Americans tended to be more neutral in their opinions than the Finns and the Chinese, the cases where they exhibited extreme opinions suggest that they give emphasis to profitability of business at the expense of moral issues. They agreed the most, for example, with statements like "A person who is doing well in business does not have to worry about moral problems" and "For every decision in business the only question I ask is, "will it be profitable?' If yes - I will act accordingly; if not, it is irrelevant and a waste of time."

By examining the ranks of the item means, there were significant differences in a total of 20 items. Of these items, perhaps surprisingly, the Americans gravitated the most toward neutralism by agreeing the most with only 
two statements (16 and 20) and disagreeing the most in only one statement (3). The Chinese students exhibited the most agreements with eight statements $(4,5,8,10,14,17,22$, and 24), while the Finns generally disagreed the most with five statements $(16,17,20,23$, and 29). Of interest is that these results are in contrast to the conclusions offered by Lin (1999) that Chinese students had more moderate attitudes because of cultural differences whereby Chinese rarely express strong agreement or disagreement.

\section{Differences By Major}

The second hypothesis stated that there would be a relationship between the students' scores on the ATBEQ and their major. Chi-Square -testing revealed such relationships in 14 of the 30 statements. In nine statements $(1,3,6,9,11,14,18,19$, and 30) students that majored in science and engineering scored the highest on the ATBEQ. In four statements $(21,22,23$, and 27) students majoring in business scored highest and liberal arts majors scored highest only on statement 16 . When considering the strongest disagreements in the statistically significant cases students majoring in science and engineering scored lowest in four statements $(16,21,22$, and 23). Business majors scored lowest in four statements as well $(6,18,19,10)$ and liberal arts majors in five statements $(1$, $3,9,11$, and 27). In statement 14 there was no difference between the three groups.

When looking at the most extreme opinions on the ATBEQ, students majoring in science and engineering had either the most positive or negative opinions on thirteen of the fourteen statements that differed statistically between majors. They were followed by business majors who had extreme opinions on eight statements. Liberal arts majors seem to be the most neutral in their opinions, as only in six instances were they recorded to have either the most extreme positive or negative opinions. It seems that the most derivative opinions come from the science majors. The most agreement was found between business and liberal arts majors, as they exhibited opposite opinions only in one instance (statement 27). Students majoring in science and engineering, on the other hand, seem to have equally differing opinions between business majors (opposite opinions in seven statements) and liberal arts majors (opposite opinions in five statements).

In the US data the pairwise t-testing showed differences in five statements $(2,4,19,26$, and 27). In the Finnish data differences were found in statement 11 , where science and engineering majors showed more agreement than the business majors. There were no liberal arts majors in the Finnish data. Additionally, the Chinese data did not include the students' majors.

\section{Differences By Class Year}

According to the third research hypothesis, the students' class year should impact their attitudes toward business ethics. This research hypothesis is supported by 22 of the 30 statements in the ATBEQ according to ChiSquare -testing. Seniors tend to agree the most with the research statements, as they exhibited the most agreements in 12 statements. In majority of the cases the fewer years the respondent had been a student, the more he or she tended to disagree with the research statements with the exception that juniors showed the most disagreement in one statement (statement 20). Cases where the most disagreements came from students that had been enrolled in their institutions fewer years than students that agreed the most were found in 12 (statements 1, 4, 5, 7, 8, 14, 16, 20, 21, and 22).

The results in general would support the assumption that the opinions tend to shift towards agreement along with school years. In only three statements $(6,15$, and 18$)$ did seniors show the most disagreement, and interestingly in all these three statements sophomores exhibited the most agreement. There is a possibility that freshmen have not yet had enough experience or lack the confidence in forming their opinions, as they exhibited extreme opinions in only four statements $(1,2,7$, and 21$)$, all with disagreement.

In the US data the only extreme findings were items 1 and 8 , where freshmen showed more agreement than sophomores (item 1) or juniors (item 8). There were no difference between freshmen and seniors. In the Finnish data similar findings of more agreement were exhibited in statements 1 and 15. Statement 24 showed the more disagreement. In contrast, the Chinese data showed more positive attitudes toward business ethics by sophomores. In items 1,14 , and 22 there were differences between sophomores and juniors, and in item 4 a difference between 
sophomores and seniors. Additionally, in statement 27, juniors agreed more than sophomores or seniors. There were no freshmen in the Chinese data.

\section{Differences By GPA}

The fourth hypothesis stated that there is a relationship between students' scores on the ATBEQ and their GPA's. Since the US grades tended to be skewed to the right, the SPSS branded variable procedure was used. This created a grade variable with three categories. The bottom third $(48.6 \%)$ of the students fell between 0 and 3 , the middle third (18.8\%) between 3.01 and 3.30, and the top third (32.6\%) above 3.30. In the US data t-testing revealed differences in items $1,2,8,9,12,13,14,20,22,25,27,28$, and 30 , where all but items 12 and 25 suggested that the higher the respondent's GPA, the more likely he or she was going to disagree with the ATBEQ statements. The Finnish data were also divided into three categories with approximately 33 percent of students in each category. Of interest were statements such as 15 where the students with the highest GPA tended to agree the most with the this statement, while in item 27, students with the lowest GPA tended to agree the most. The Chinese data lacked the sufficient amount of self-reported GPA's to make any kinds of scientific conclusions.

\section{Differences By Gender}

The next research hypothesis states that there should be no differences between the respondents' attitudes toward business ethics and their gender. ANOVA and pairwise t-testing did reveal such relationships in 18 items (1, $2,3,7,9,10,13,17,18,20,21,22,23,26$, and 27) in the US data, in 4 items $(2,4,6$, and 23) in the Finnish data, and one item in the Chinese data (item 27). In all these cases except for the Chinese case, men exhibited more positive attitude towards the business ethics statements. Therefore the fifth research hypothesis is rejected by 23 out of the 30 statements. Men exhibited clearly more agreement with the ethics statements than women. In 18 statements men had more extreme positive opinions than women, where only two instances were found. The remaining three statistically significant instances were somewhat harder to interpret. For example in statement 10 ("The business world today is not different from what it used to be in the past") men and women had almost the same response percentages compared to all other answering options, but men had more responses in the "Strongly disagree" category and women had proportionally more responses in the "Disagree" category. Further, nonparametric testing suggested that men and women did differ in their opinions in that question, and men did have statistically more extreme negative opinions.

Interestingly the data also suggested that while men tended to agree more with the research statements, in many cases they also had the most extreme disagreements at the same time. Whether this shows a generally abstinent nature of the male mind, or some fundamental difference between the answering patterns between the genders is unclear. However, in 70 percent of the cases, women exhibited clear tendency toward neutral behavior. This, in conjunction with the fact that women did not show any signs of extreme opinions, might suggest that women have a higher threshold of stating their opinions, and do not like to stray too far away from neutralism.

\section{Differences By Age}

The sixth research hypothesis stated that there should be a relationship between the students' ethics scores and their age. Since the dependent variable (age) is a scale variable, analysis of variance (ANOVA) was performed to examine $\mathrm{H}_{6}$. In 18 of the 30 statements support for the sixth research hypothesis was provided. As ANOVA only tells whether the group means are equal or not, post hoc analysis was done by pairwise t-tests between the different opinion groups.

The results could be divided in four categories. The first category showed clear increasing disagreement with age. Altogether seven statements $(2,16,20,21,22,23$, and 29) were included in the first category. In the second category the agreement increased with age. This was noted in four instances $(3,18,26$, and 30$)$. In five statements $(6,9,13,14$, and 17) the distribution had a distinct v-like shape, where the oldest respondents accounted for both the negative and positive opinions while younger people tended to be more neutral. In two cases (12 and 28) younger and older respondents alternated between agreement and disagreement so that no linear relationship could be found. When looking at categories one and two, and the corresponding statements, a certain pattern can be seen. 
In most cases the older the respondent, the more he/she seems to be concerned with moral issues. For example, statement 2 ("A person who is doing well in business does not have to worry about moral problems.") belonged to category one, where older respondents thought that doing well in your business does not liberate you from moral issues. On the other hand statement 2 ("Every business person acts according to moral principles, whether he/she is aware of it or not.") belonged to category two where older respondents thought that moral principles are part of business.

\section{Differences By Number of Ethics Courses}

The Finnish institution in the sample did not offer any ethics courses, so there were no data available. Therefore, the Finnish respondents were omitted from this research hypothesis and only the US and Chinese samples were used. Since $95.6 \%$ of the respondents had completed three or less ethics courses, they were divided into three groups. The first group had not completed any ethics courses, and serve as a reference group. Students in the second group had completed one or two ethics courses, and can be considered as a group with some insight into ethics. The third group consisted of students with three or more ethics courses completed, and are considered as a group with the deepest knowledge, and possibly interest, in ethics-related issues.

The aforementioned groups were tested against their scores on the ATBEQ by Chi-Square testing, and in statistically significant cases the direction of the relationship was determined on a case-by-case basis. Significant differences were found in 16 cases. By examining the distributions of these groups more closely, positive relationships with the ATBEQ scores and the number of ethics courses completed was found in nine cases $(3,4,5$, $8,10,14,22,24$, and 26) which does not provide very strong support for $\mathrm{H}_{7}$. However by closer examination, it seems that the ethics courses have at least some impact on students' opinions. For example, there is a clear positive correlation between the number of ethics courses completed and questions like "Every business person acts according to moral principles, whether he/she is aware of it or not" and clear negative correlation with questions like "Business decisions involve a realistic economic attitude and not a moral philosophy" and "As a consumer when making a car insurance claim, I try to get as much as possible regardless of the extent of the damage."

When looking at the number of ethics courses undertaken by the respondents, it was found that most of the US students $(69 \%)$ had not completed a single ethics course, and only 83 of the $772(11 \%)$ of the respondents had taken two or more ethics courses. This provided a natural three-way classification where the first group had taken no ethics courses $(n=533)$, the second group completed only one ethics course $(n=156)$, and the third group had taken two or more courses in ethics $(n=88)$. The t-testing in the US data revealed differences in five statements $(9,12,18$, 25, and 29). To ease the comparison the Chinese data were divided into three categories as well. The first group had completed only one ethics course or no ethics courses $(n=45)$, the second group had completed two or three ethics courses $(n=51)$, and the third group had taken four or more ethics courses $(n=37)$. The $t$-testing revealed differences in statements 2, 12, and 22. Statement 12 was similar to the US data, and in statement 22 it was clear that students with more than four ethics courses disagreed the most with the statement. The Finnish institution in the sample did not offer any ethics courses, so there were no data available.

\section{Differences By Number of Religious Courses}

Similarly, the Finnish institution did not offer any kinds of religious courses, so only the US and China data were available for analysis of hypothesis 8 . In both data sets the sample was divided into three categories to facilitate comparisons with $\mathrm{H}_{8}$. In both US and China data sets the first group consisted of students with no credited religious courses (USA: $n=523$ ), (China: $n=95$ ), the second group had only one completed religious course (USA: $\mathrm{n}=103$ ), (China: $\mathrm{n}=14$ ), and the third group had two or more (USA: $\mathrm{n}=145)$, (China: $\mathrm{n}=12$ ).

When Chi-Square testing was performed across the aforementioned groups, it became clear that there was not be enough evidence to support hypothesis 8 . In only $10(4,8,9,14,17,18,21,23,27$, and 29) of the 30 statements did the Chi-Square testing reveal statistical differences between the control groups. Furthermore in these 10 statements in two cases (9 and 29) the relationship with the ATBEQ scores and the number of religious courses was positive. This leaves us with eight statistically significant statements to back up the hypothesis of a uniform relationship, which is not sufficient. 
In the US data t-testing revealed that the more religious studies courses the respondent had completed, the more likely he or she was to disagree with statements $2,6,7,8,9$, and 17.

\section{Differences By Opinion Leadership Index}

The final research hypothesis stated that there would be a positive correlation between students' attitudes toward business ethics scores and their scores on the Revised Opinion Leadership Scale. Like age, the opinion leadership index can be thought as a scale variable, and thus, the analysis of variance can be performed to study the relationships in $\mathrm{H}_{9}$. Post hoc t-testing was once again used to verify the directions of statistically significant differences between the different group means. ANOVA provides strong evidence for this research hypothesis, as in 24 of the 30 cases the opinion leadership index means differed statistically across the ATBEQ statements.

However, in 16 of these 24 statements the opinion leadership index means distributions mimicked the normal curve, so if there is a relationship, it is not likely to be linear like it was hypothesized to be. Positive relationships were found in only five statements $(9,16,20,22$, and 23). When examining the statements that correlated positively with the opinion leadership index, it seems that opinion leaders do not put much emphasis on issues like ethics, but rather on the profitability of business according to their opinions ("For every decision in business the only question I ask is, "will it be profitable?" If yes - I will act accordingly; if not, it is irrelevant and a waste of time," "A business person can't afford to get hung on ideals").

For consistency, the opinion leadership indexes were divided into three categories. The lowest third (scores 6 to 19) were indicated as "High Opinion Leadership" group, while the middle third (scores 20-23) were tagged as "Moderate Opinion Leadership", and the highest third (scores 24-30) as "Low Opinion Leadership". After applying the ANOVA three significant cases were of interest in the US data $(11,12$, and 26). With statement 11, the differences emerged between the moderate and high opinion leadership groups in such a way that the high group scored higher than the moderate group. With statements 12 and 26 the differences were found between the moderate and low groups. In both cases the low group scored less than the moderate group. Both in the Finnish and Chinese data only one significant statement was found but neither of them passed both the Analysis of Variance tests.

\section{CONCLUSIONS}

There were differences in attitudes toward business ethics seen by country after applying Lin's ranking component methodology and using Moore and Radloff cumulative impact rule in that significant differences were found in a total of 20 items. Americans gravitated the most toward neutralism by agreeing the most with only two statements and disagreeing the most in only one statement. The Chinese students exhibited the most agreements with eight statements and the Finns generally disagreed the most with five statements. Of interest is that these results are in contrast to the conclusions offered by Lin (1999) that Chinese students had more moderate attitudes because of cultural differences whereby Chinese rarely express strong agreement or disagreement.

With respect to the students' majors, only 14 ethical statements were determined to be significant. Therefore, differences between attitudes toward business ethics and major area of study were not supported according to the 50 percent cumulative impact rule.

The impact of the students' class year on their attitudes toward business ethics was also supported by 22 of the 30 statements. In general the findings lead to the assumption that the opinions of students tend to shift towards agreement along with school years. The more years the respondent had been a student, the less likely he or she was to disagree with the research statements.

Although all statements except two for the US suggested that the higher the respondents' GPA, the more likely he or she was going to disagree with the ATBEQ statements, the 50 percent rule does not allow this finding to qualify with only 13 statements found to be significantly different.. The relationship between GPA and business ethics attitudes was not supported for Finnish students. 
The support for the gender research hypothesis is strong with 23 statements found to be significant. It was revealed that men (except Chinese) exhibited more positive attitudes towards the business ethics statements than women. Women exhibited a clear tendency toward neutral behavior in 70 percent of the cases. This, in conjunction with the fact that women did not show any signs of extreme opinions, might suggest that women have a higher threshold of stating their opinions, and do not like to stray too far away from neutralism.

In 16 of the 30 statements support was found for the relationship between age and ethical attitudes. In a majority of cases, the older the respondent, the more he/she seemed to be concerned with moral issues.

With respect to the number of ethics and religious courses completed, a positive relationship was found in only nine and ten cases respectively. Therefore these two hypotheses are not supported according to the Moore and Radloff methodology.

The ninth research hypothesis, which was to determine if there was a relationship between students' attitudes toward business ethics and their opinion leadership, revealed in 24 of the 30 cases the opinion leadership index means differed statistically across the ATBEQ statements. However, positive relationships were found in only five statements. After examination of the statements that correlated positively with the opinion leadership scores, it appears that opinion leaders do not put much emphasis on issues involving ethics, but rather on the profitability of business. This is an interesting finding that suggests that the managers of the future who are also strong opinion leaders, and therefore may have greater influence over others, may be more concerned with business profits than business ethics.

As business schools prepare the executives of the future in today's global economy, an understanding of ethical attitudes within and across cultures is essential. Business schools must continue to assess their performance so that improvements in ethical training and curricula may be implemented. The conclusions of this research suggest that the attitudes toward business ethics of the students in the US, Finland, and China do significantly differ and opinion leadership is somewhat related to ethical attitudes in the three countries.

\section{AUTHOR INFORMATION}

Charles Comegys, Ph.D. is Ciejek Chair of Business with the Francis E. Girard School of Business \& International Commerce at Merrimack College, North Andover, Massachusetts, USA. Dr. Comegys' case studies have appeared in textbooks and his articles appear in numerous journals. Dr. Comegys has been a frequent speaker in industry and at professional conferences. Additionally, Dr. Comegys has served on the Board of Directors of the Marketing Research Association, and the Board of Directors of the Marketing Educators' Association and has served on the American Marketing Association's International Board of Directors. Dr. Comegys' research interests include ethics, research methodologies, and internet purchase behavior. He can be reached at: comegysc@merrimack.edu (Corresponding author)

Dr. Robert Lupton is a Professor of Retail Management and Technology in the Information Technology and Administrative Management department at Central Washington University. His expertise is international business and marketing including research in Central Europe and China. He can be reached at: luptonr@cwu.edu

David R. Rawlinson is an Associate Professor of Information Technology Management at Central Washington University. He serves as the 2011-2014 Faculty Legislative Representative to the Washington state legislature from Central Washington University and is a Faculty Fellow for Multi-modal Learning at Central Washington University. He holds a Bachelor of Arts in Computer Science from The University of North Texas and a Juris Doctor from South Texas College of Law. He teaches Network Administration and Information Technology security courses and can be reached at: david.rawlinson@ cwu.edu

Dr. Jaani Väisänen received his $\mathrm{PhD}$ from Tampere University of Technology, Finland. His special research areas include online marketing, web analytics, customer relationship management and building social media presence. He currently works for the South Carelia Joint Authority for Education, where he works with local businesses in training their employees in the areas of marketing communications, customer relationship management and sales. 
His teaching activities also include seminars and online marketing courses for local small and medium-sized enterprises. He can be reached at: jaani.vaisanen@ek-aktiva.fi

\section{REFERENCES}

1. Arlow, P. (1991). "Characteristics in college students' evaluations of business ethics and corporate responsibility." Journal of Business Ethics, 10, 63-69.

2. Borkowski, S.C. \& Y.J. Ugras (1992). "The ethical attitudes of students as a function of age, sex, and experience.” Journal of Business Ethics, 11, 63-69.

3. Childers, T.L. (1986). "Assessment of the Psychometric Properties of an Opinion Leadership Scale." Journal of Marketing Research, 23 (May), 184-188.

4. Ethics Education Task Force to AACSB International, Ethics Education in Business Schools (2004.) St. Louis, MO AACSB International.

5. Ethics/Sustainability Resource Center AACSB, Retrieved from: http://www.aacsb.edu/resources/ethicssustainability. August 17, 2012.

6. Ferrell, O. (1999) An Assessment of the Proposed Academy of Marketing Science Code of Ethics for Marketing Educators. Journal of Business Ethics, 19 (2), 225-228.

7. Forelle, C. \& J.Bandler (2006). "The Perfect Payday; Some CEOs reap millions by landing stock options when they are most valuable; Luck - or something else?" The Wall Street Journal, (Eastern edition). New York: March 18, 2006. p. A1.

8. _ (2006). "During 1990s, "Microsoft Practiced Variation of Options Backdating" The Wall Street Journal, (Eastern edition). New York: June 16, 2006. p. A1.

9. "Glaxo Sets Guilty Plea \$3 Billion Settlement" The Wall Street Journal, New York: July 3, 2012. P. B1.

10. Glenn, J.R. (1992). "Can a business and society course effect the ethical judgment of future managers?" Journal of Business Ethics, 11(3), 217-224.

11. Grunbaum, L. (1997). "Attitudes of Future Managers Towards Business Ethics: A Comparison of Finnish and American Business Students" Journal of Business Ethics, 16(4), 451-463.

12. Hill, R. P. (1995). "Researching Sensitive Topics in Marketing - The Special Case of Vulnerable Populations." Journal of Public Policy \& Marketing, 14 (1), 143-49.

13. Institutional Shareholder Services (2006). “An Investor Guide to the Stock Option Timing Scandal,” (July), $1-7$.

14. King, C. W. and Summers J. O. (1970) "Overlap of Opinion Leadership Across Consumer Product Categories.” Journal of Marketing Research, 7 (February), 43-50.

15. Lin, C. (1999). A Comparison of Perceptions About Business Ethics in Four Countries. The Journal of Psychology, 133 (6), 641-655.

16. McCabe, D. (2006) Academic Dishonesty in Graduate Business Programs: The Prevalence, Causes, and Proposed Actions. Academy of Management Learning and Education Journal, forthcoming.

17. Mitroff, I. \& D. Swanson (2004). "An Open Letter to the Deans and the Faculties of American Business Schools: A Call for Action." The Academy of Management News, (35) 7-8.

18. Moore, R. and Radloff, S. (1996). Attitudes Towards Business Ethics Held by South African Students. Journal of Business Ethics, 15, 863-869.

19. Okleshen, M. \& R. Hoyt (1996). "A cross cultural comparison of ethical perspectives and decision approaches of business students: United States of America versus New Zealand. Journal of Business Ethics, 15, 537-549.

20. Preble, J. and Reichel A. (1988). Attitudes Towards Business Ethics of Future Managers in the U.S. and Israel. Journal of Business Ethics, 7, 941-949.

21. Rogers, E.M. (1961) Characteristics of Innovation and Other Adopter Categories. Wooster, Ohio: Ohio Agricultural Experiment Station Research Bulletin 882.

22. Salmans, S. (1987). "Suddenly business schools tackle ethics." New York Times Education Life, August 2, 64-69.

23. Shepard, J.M., \& L.S. Hartenian (1990). "Egoistic and ethical orientations of university students toward work-related decisions." Journal of Business Ethics, 10, 303-310.

24. and Cartano, D. G. (1962) "Methods of Measuring Opinion Leadership" Public Opinion Quarterly 26 (Fall) 435-441. 
25. Sims, R. \& Gegez A. E. (2004). Attitudes Towards Business Ethics: A Five Nation Comparative Study. Journal of Business Ethics, 50, 253-265.

26. Small, M. (1992). Attitudes Towards Business Ethics Held by South African Students. Journal of Business Ethics, 11, 745-752.

27. Stevens, G. (1984). "Business ethics and social responsibility: The responses of present and future managers." Akron Business and Economics Review, 15, 6-11.

28. Terpstra, D.E., E.J. Rozell, \& R.K. Robinson (1993). "The influence of personality and demographic variables on ethical decisions related to insider trading." Journal of Psychology, 127, 375-389.

29. Wholihan, J. (2006). A Message from the BGS President. BGS International Exchange, 5 (3), 2. Retrieved October 2, 2006 from www.betagammasigma.org. 


\section{EXHIBIT 1: Attitude Toward Business Ethics Questionnaire (ATBEQ)}

Reflect on the following statements about business attitudes. Indicate your position regarding each statement by circling the number which is closest to your view.
1. Strongly disagree
2. Disagree
3. Not sure
4. Agree
5. Strongly agree

1. The only moral of business is making money.

2. A person who is doing well in business does not have to worry about moral problems.

3. Every business person acts according to moral principles, whether he/she is aware of it or not.

4. Act according to the law, and you can't go wrong morally.

5. Ethics in business is basically an adjustment between expectations and the way people behave.

6. Business decisions involve a realistic economic attitude and not a moral philosophy.

7. Moral values are irrelevant to the business world.

8. The lack of public confidence in the ethics of business people is not justified.

9. "Business ethics" is a concept for public relations only.

10. The business world today is not different from what it used to be in the past. There is nothing new under the sun.

11. Competitiveness and profitability are independent values (existing on their own).

12. Conditions of a free economy will serve best the needs of society. Limiting competition can only hurt society and actually violates basic natural laws.

13. As a consumer when making a car insurance claim, I try to get as much as possible regardless of the extent of the damage.

14. While shopping at the supermarket, it is appropriate to switch price tags or packages.

15. As an employee, I take office supplies home; it doesn't hurt anyone.

16. I view sick days as vacation days that I deserve.

17. Employee wages should be determined according to the laws of supply and demand.

18. The main interest of shareholders is maximum return on their investment.

19. George X says of himself, "I work long, hard hours and do a good job, but it seems to me that other people are progressing faster. But I know my efforts will pay off in the end." Yes, George works hard, but he's not realistic.

20. For every decision in business the only question I ask is, "Will it be profitable?" If yes - I will act according; if not, it is irrelevant and a waste of time.

21. In my grocery store every week I raise the price of a certain product and mark it "on sale". There is nothing wrong with doing this.

22. A business person can't afford to get hung up on ideals.

23. If you want a specific goal, you have got to take the necessary means to achieve it.

24. The business world has its own rules.

25. A good business person is a successful business person.

26. I would rather have truth and personal responsibility than unconditional love and belongings.

27. True morality is first and foremost self-interested.

28. Self-sacrifice is immoral.

29. You can judge a person according to his work and his dedication.

30. You should not consume more than you produce. 


\section{EXHIBIT 2: Opinion Leadership Scale}

Please rate yourself on the following scales relating to your interactions with friends and neighbors regarding business ethics.

1. In general, do you talk to your friends and neighbors about business ethics:

Very often

Never

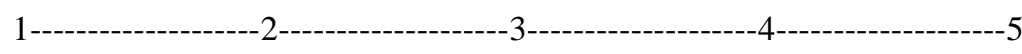

2. If you talk to your friends and neighbors about business ethics, do you:

Give a great deal of information

\section{Give very little} information

3. During the past six months, how many people have you talked with about business ethics?

Talked with a number of people
Talked with no one

4. Compared with your circle of friends, how likely are you to be asked about business ethics?

Very likely

to be asked
Not at all likely

to be asked

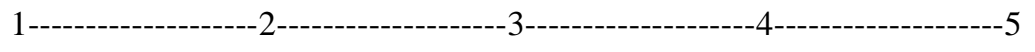

5. In discussions of business ethics, which of the following happens most often:

You tell your friends

about business ethics

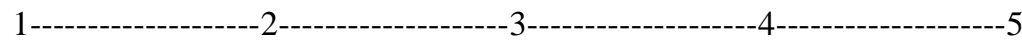

6. Overall in all of your discussions with friends and neighbors are you:

Often used as a source of information

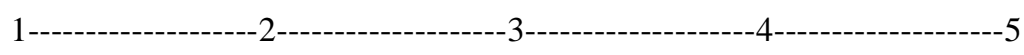

Your friends tell you about business ethics
Not used as a source of information 